\title{
PENENTUAN POHON RENTANG MINIMUM BERDASARKAN KONDISI GEOGRAFIS SUATU WILAYAH DENGAN ALGORITMA PRIM
}

\author{
Hadiyanto ${ }^{1)}$, Muhamad Alhan ${ }^{2)}$ \\ ${ }^{(1)}$ Teknik Elektro, Sekolah Tinggi Teknologi Bontang, \\ Kalimantan Timur, Indonesia \\ e-mail : siemenshd@gmail.com \\ ${ }^{(2)}$ Teknik Elektro, Politeknik Pratama Mulia \\ Surakarta 57149 , Indonesia \\ e-mail : yuesss08@gmail.com
}

\begin{abstract}
Determination of the minimum spanning tree are widely used to solve optimization problems of finding solutions to problems that require minmum. In the electricity distribution network, minimum spanning tree (MST) is used to find the minimum length of cable for electricity network system becomes more optimal. Minimum weight of a MST primary distribution power network is strongly influenced by the geographical conditions of a region in the form of contour data. This research was done by designing a model of primary distribution power network graph in accordance with the data obtained. In finding the minimum weight for each side of the network graph should include parameters elevation, high point / node, and the distance between points / nodes. Furthermore, the graph is done by computer calculation and simulation to get the electricity distribution network primary MST using Prim's algorithm with the help of ArcView GIS 3.3 program through the avenue script.

Prim's algorithm included in the category of good or efficient algorithms, because the shape of polynomial time complexity in $n$, where $n$ is a measure of the number of vertices or sides. Based on the test results have shown that the algorithm Prim MST ability to determine the primary distribution grid is much better if based on the geographical conditions of a region. In addition, Prim's algorithm graph computation time in generating the MST based on the data that is not based on the contour and contour data are quadratic.
\end{abstract}

\section{Keywords: minimum spanning tree, prim's algorithm, contours, complexity time}

Penentuan pohon rentang minimum yang banyak digunakan untuk memecahkan masalah optimasi untuk menemukan solusi terhadap masalah yang memerlukan minmum. Dalam jaringan distribusi listrik, pohon rentang minimum (MST) digunakan untuk menemukan panjang minimal kabel untuk sistem jaringan listrik menjadi lebih optimal. Bobot minimum dari jaringan listrik MST distribusi primer sangat dipengaruhi oleh kondisi geografis suatu daerah dalam bentuk data kontur. Penelitian ini dilakukan dengan merancang model distribusi tenaga listrik grafik jaringan primer sesuai dengan data yang diperoleh. Dalam mencari bobot minimum untuk setiap sisi grafik jaringan harus mencakup elevasi parameter, titik tinggi / simpul, dan jarak antara titik / node. Selain itu, grafik dilakukan dengan perhitungan dan simulasi komputer untuk mendapatkan distribusi listrik jaringan primer MST menggunakan algoritma Prim dengan bantuan ArcView 3.3 Program GIS melalui script jalan.

Algoritma Prim termasuk dalam kategori algoritma yang baik atau efisien, karena bentuk kompleksitas polinomial waktu dalam $\mathrm{n}$, dimana $\mathrm{n}$ adalah ukuran dari jumlah simpul atau sisi. Berdasarkan hasil pengujian menunjukkan bahwa algoritma Prim kemampuan MST untuk menentukan jaringan distribusi utama adalah jauh lebih baik jika didasarkan pada kondisi geografis suatu daerah. Selain itu, algoritma Prim grafik perhitungan waktu dalam menghasilkan MST berdasarkan pada data yang tidak didasarkan pada kontur dan data kontur yang kuadratik.

Kata kunci: minimum spanning tree, algoritma prims, kontur, kompleksitas waktu 


\section{PENDAHULUAN}

Penggunaan pemodelan pohon rentang minimum adalah salah satu pemodelan graf yang digunakan untuk mencari nilai minimum dari jalur pada suatu graf, atau dengan kata lain menentukan jarak terpendek suatu titik dengan titik lainnya dengan melewati titik-titik yang ada diantaranya. Untuk mendapatkan hasil tersebut, maka dipilih ruas graf yang memenuhi kriteria dari optimasi yang akan menghasilkan biaya minimum.

Pada saat ini, minimum spanning tree (pohon rentang minimum) telah banyak digunakan di berbagai aplikasi salah satunya pada penentuan pohon rentang minimum jaringan distribusi listrik. Penggunaan pohon rentang minimum disesuaikan atas kebutuhan dan ketepatan implementasi di lapangan, sehingga menghasilkan solusi yang optimal. Solusi yang optimal (terbaik) merupakan solusi yang bernilai minimum atau maksimum dari sekumpulan alternatif solusi yang mungkin terjadi.

Terdapat beberapa algoritma yang dipakai dalam membangun pohon rentang minimum (MST), diantaranya algoritma prim. Untuk menghasilkan pohon rentang minimum yang optimal diperlukan pemilihan algoritma yang bagus dan benar. Algoritma yang bagus dan benar adalah algoritma yang tepat atau efisien untuk diterapkan pada graf jenis tertentu.

Penentuan pohon rentang minimum menggunakan algoritma prim harus memperhatikan bobot minimum dari masing-masing ruas graf untuk menghasilkan minimum spanning tree (MST) dengan bobot minimum. Nilai suatu bobot graf sangat bervariasi tergantung dari jenis kasus yang dikerjakan. Contohnya pada kasus penentuan pohon rentang minimum pada jaringan distribusi listrik, dimana bobot graf tersebut di implementasikan dalam bentuk panjang kabel listrik yang menghubungkan tiang-tiang distibusi listrik.

Bobot graf berupa panjang kabel listrik dipengaruhi oleh beberapa parameter, diantaranya kondisi geografis suatu wilayah. Seperti diketahui, kondisi geografis di suatu wilayah berbedabeda khususnya dalam hal ketinggian permukaan bumi. Ketinggian suatu permukaan bumi merupakan suatu bagian data spasial yang berbentuk data kontur pada sistem informasi geografis.

Diharapkan dengan adanya parameter ketinggian dari data kontur suatu wilayah dalam penentuan bobot minimum untuk menghasilkan pohon rentang minimum dengan algoritma prim, maka akan diperoleh panjang minimum kabel listrik yang mendekati kenyataan untuk menghubungkan tiang-tiang listrik distribusi.

Disamping itu, penggunaan kabel listrik yang terlalu panjang pada jaringan listrik akan mempengaruhi kualitas tegangan pelayanan dan kualitas keandalan jaringan listrik. Kualitas tegangan pelayanan dipengaruhi oleh besar kecilnya jatuh tegangan yang ditimbulkan pada ujung-ujung kabel jaringan listrik tersebut. Sedangkan kualitas keandalan listrik dipengaruhi oleh intensitas dan lamanya pemadaman listrik yang terjadi.

Dalam penelitian ini akan dibuat suatu model jaringan distribusi listrik primer yang telah ada di Kota Samarinda kedalam suatu bentuk graf dengan bobot yang telah ditentukan berdasarkan kondisi geografis Kota Samarinda untuk menghasilkan pohon rentang minimumnya. Selanjutnya dilakukan simulasi dan perhitungan oleh bantuan program komputer untuk mendapatkan pohon rentang minimum pada jaringan distribusi listrik primer dengan menggunakan algortima prim.

\section{METODE PENELITIAN}

\section{Bahan Penelitian}

Data yang dikumpulkan dalam penelitian ini digunakan untuk menjawab pertanyaan penelitian yang telah dirumuskan, karena data yang diperoleh akan dijadikan landasan dalam mengambil kesimpulan. Adapun metode pengumpulan data yang digunakan dalam penelitian ini, antara lain:

1. Studi literatur, yaitu penelusuran literatur mengenai dasar pengetahuan tentang hal-hal yang berkaitan dengan penelitian ini. Metode ini dilakukan dengan cara mencari buku-buku, artikel-artikel, dan jurnal-jurnal ilmiah mengenai algoritma yang merupakan salah satu cabang ilmu komputer, khususnya mengenai graf, pohon rentang minimum, dan algortima prim. Selain itu juga dilakukan penelusuran tentang data spasial yang ada pada sistem informasi geografis (GIS). Data spasial yang digunakan adalah data kontur yang menjelaskan ketinggian permukaan bumi suatu daerah/wilayah. 
2. Pengumpulan data jaringan distribusi listrik yang diperoleh dari PT. PLN (Persero) Cabang Samarinda. Data yang diperoleh adalah data digitasi jaringan listrik distribusi primer (jaringan tegangan menengah) dengan beberapa penyulang (feeder) di wilayah kerja PT. PLN (persero) Cabang Samarinda. Proses pengambilan data digitasi tiang listrik distribusi, gardu distribusi, dan LBS/ABS dilakukan oleh PT. PLN Cabang Samarinda dengan menggunakan metode satelit penginderaan jauh berupa alat global positioning system (GPS).

3. Pengumpulan data peta topografi wilayah Kota Samarinda yang diperoleh dari Dinas Pertambangan dan Energi Kota Samarinda. Data yang digunakan adalah data kontur, data luas wilayah, serta beberapa data sungai dan landmark. Metode pengambilan data peta topografi menggunakan metode fotogrametri (foto udara) dan divalidasi dengan survey topografi oleh Bakosurtanal (Badan koordinasi survey dan pemetaan nasional).

4. Melakukan pengamatan secara langsung pada jaringan listrik distribusi primer yang di wilayah Kota Samarinda untuk disesuaikan dengan data yang diperoleh dari PT. PLN (Persero) Cabang Samarinda

Tahapan Penelitian

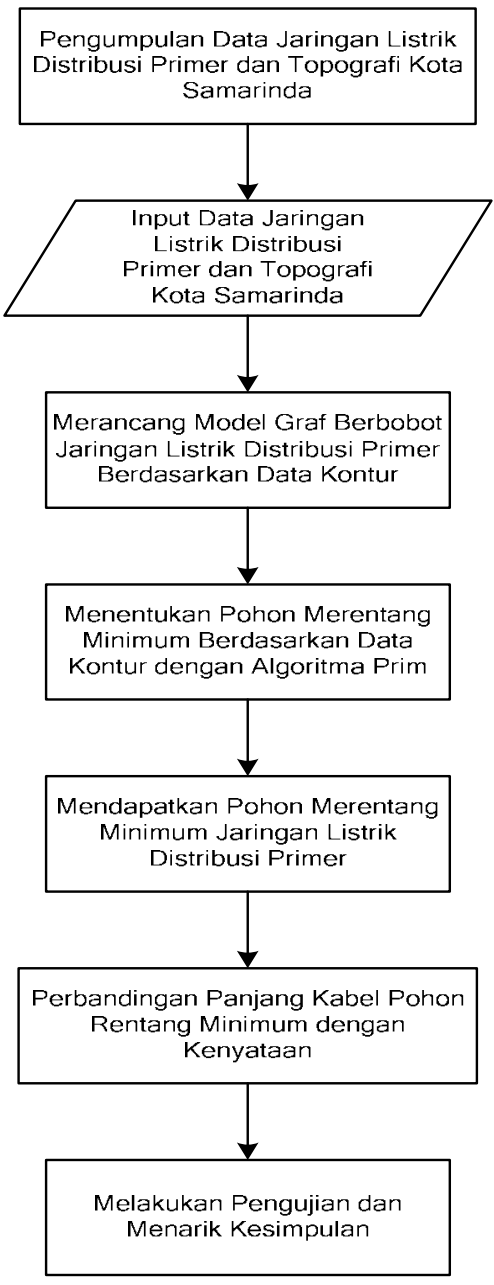

Gambar 1. Tahapan Penelitian

\section{Perancangan Sistem}

Diagram konteks merupakan pola penggambaran yang berfungsi memperlihatkan interaksi sistem dengan lingkungan dimana sistem tersebut ditempatkan (Oetomo, 2002). Dari analisa yang dilakukan, maka diperoleh diagram konteks dari penentuan pohon rentang minimum berdasarkan kondisi geografis suatu wilayah menggunakan algortima prim dengan studi kasus pada Kota Samarinda yang dijelaskan pada Gambar 2. 


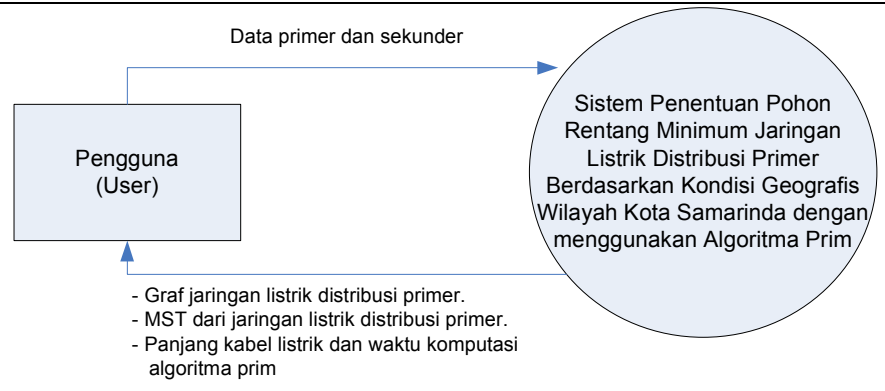

Gambar 2. Diagram konteks penentuan pohon rentang minimum

Berdasarkan Gambar 2, pengguna (user) pada sistem ini memasukkan data sekunder berupa data geografis wilayah Kota Samarinda, antara lain; data bangunan, data jalan, serta data sungai (peta topografi). Selain itu juga user memasukkan data primer berupa data jaringan listrik distribusi primer dan data kontur, antara lain; data tiang listrik distribusi primer, data saluran udara tegangan menengah (SUTM) pada masing-masing penyulang (feeder), data gardu distribusi, data LBS (load breaker switch), serta data jarak antara tiang listrik distribusi primer, antara gardu distribusi, atau antara LBS.

Diagram alir data (DAD) menggambarkan penyimpanan data dan proses yang mentransformasikan data. DAD menunjukkan hubungan antara data pada sistem dan proses yang mengikutinya. Adapun DAD pada sistem penentuan pohon rentang minimum berdasarkan kondisi geografis suatu wilayah menggunakan algortima prim dengan studi kasus pada Kota Samarinda dapat dijelaskan pada Gambar 3 dalam bentuk DAD level 0;

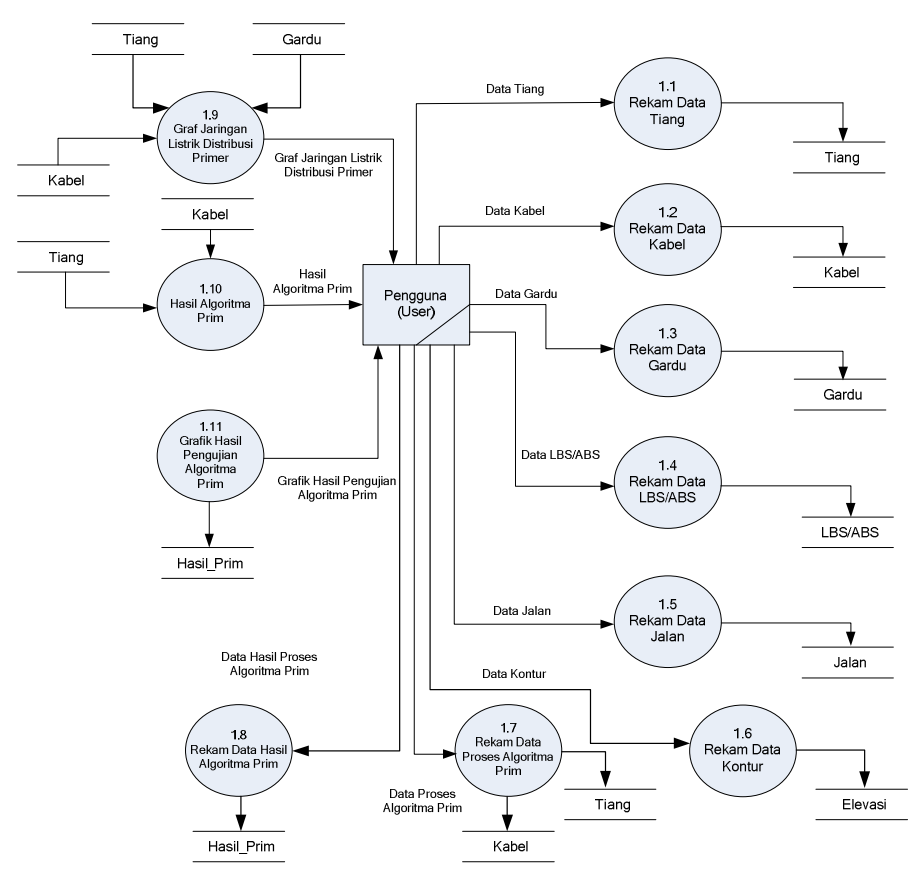

Gambar 3. Diagram alir data level 0 pada sistem algoritma prim

Secara garis besar, Gambar 3 memiliki beberapa proses dalam diagram alir data (DAD) level 0 pada sistem algoritma prim dengan menggunakan program ArcView GIS 3.3. Terdapat beberapa proses yang terjadi pada Gambar 3 meliputi :

1. Proses rekam data tiang listrik distribusi.

2. Proses rekam data kabel SUTM.

3. Proses rekam data gardu distribusi.

4. Proses rekam data LBS/ABS. 
5. Proses rekam data jalan.

6. Proses rekam data kontur

7. Proses rekam data untuk penentuan MST dengan algoritma prim.

8. Proses rekam data hasil penentuan MST pada algoritma prim.

9. Proses menampilkan graf jaringan listrik distribusi primer.

10.Proses menampilkan pohon rentang minimum dari algoritma prim.

11.Proses menampilkan grafik hasil pengujian algoritma prim.

Program yang dibangun dengan ArcView GIS 3.3 tersebut menggunakan beberapa tabel pada basis datanya, diantaranya tabel tiang, tabel kabel, tabel gardu, tabel LBS/ABS, tabel jalan, dan tabel kontur. Relasi antar tabel-tabel tersebut diperlihatkan pada Gambar 4.

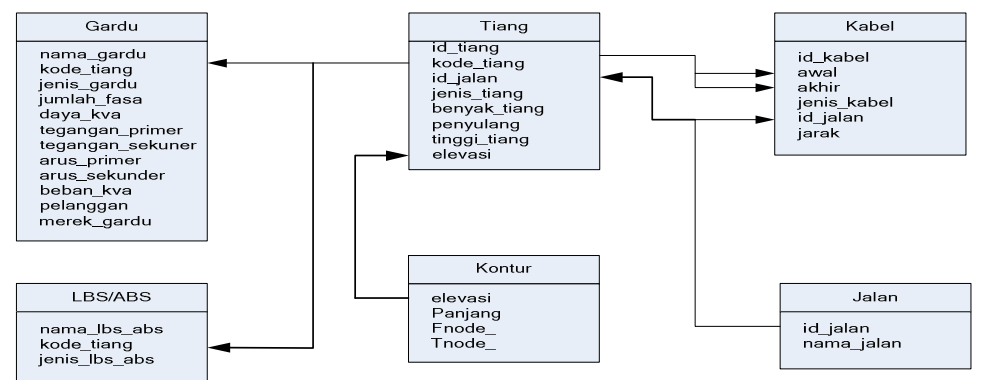

Gambar 4. Relasi antar tabel dalam algoritma prim

\section{Tahapan Proses Penentuan Pohon Rentang Minimum}

Data yang diperoleh dari PT. PLN Cabang Samarinda dan Distamben Kota Samarinda berupa tiang listrik, kabel listrik, gardu distribusi, LBS/ABS, serta kontur dimasukkan ke dalam sistem dengan dukungan data peta topografi wilayah Kota Samarinda. Selanjutnya data-data tersebut diproses menggunakan metode algoritma prim yang telah dimodifikasi untuk mendapatkan hasil berupa pohon rentang minimum suatu jaringan listrik distribusi primer di wilayah Kota Samarinda dengan disertai total bobot minimum yang dihasilkannya Tahapan tersebut dapat dijelaskan dalam bentuk flowchart program pada Gambar 5.

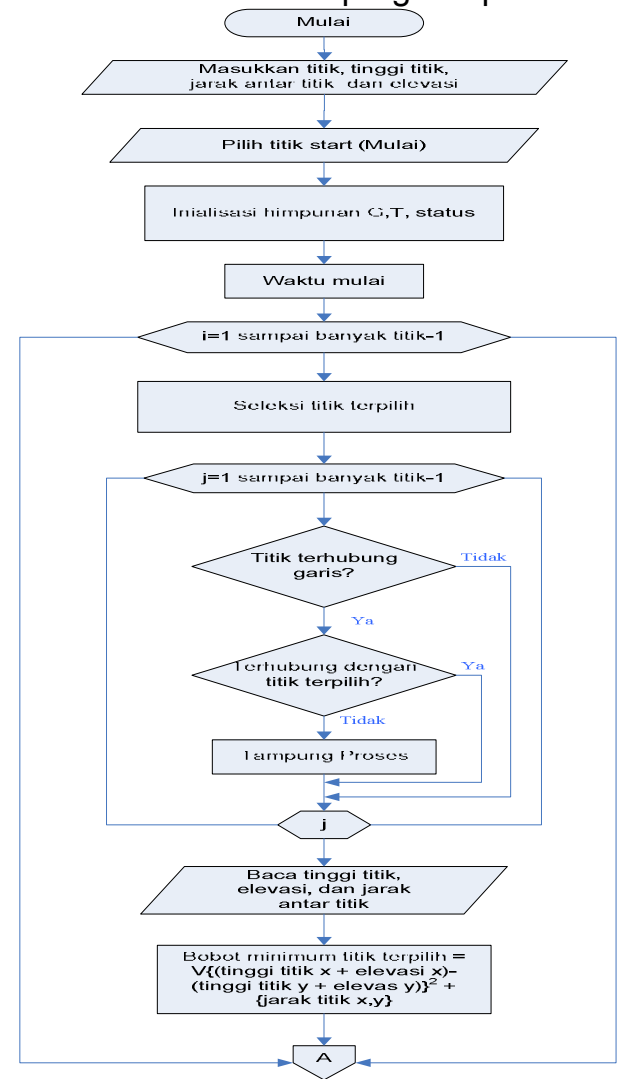

Gambar 5. Tahapan Penentuan Titik Tiang Listrik 


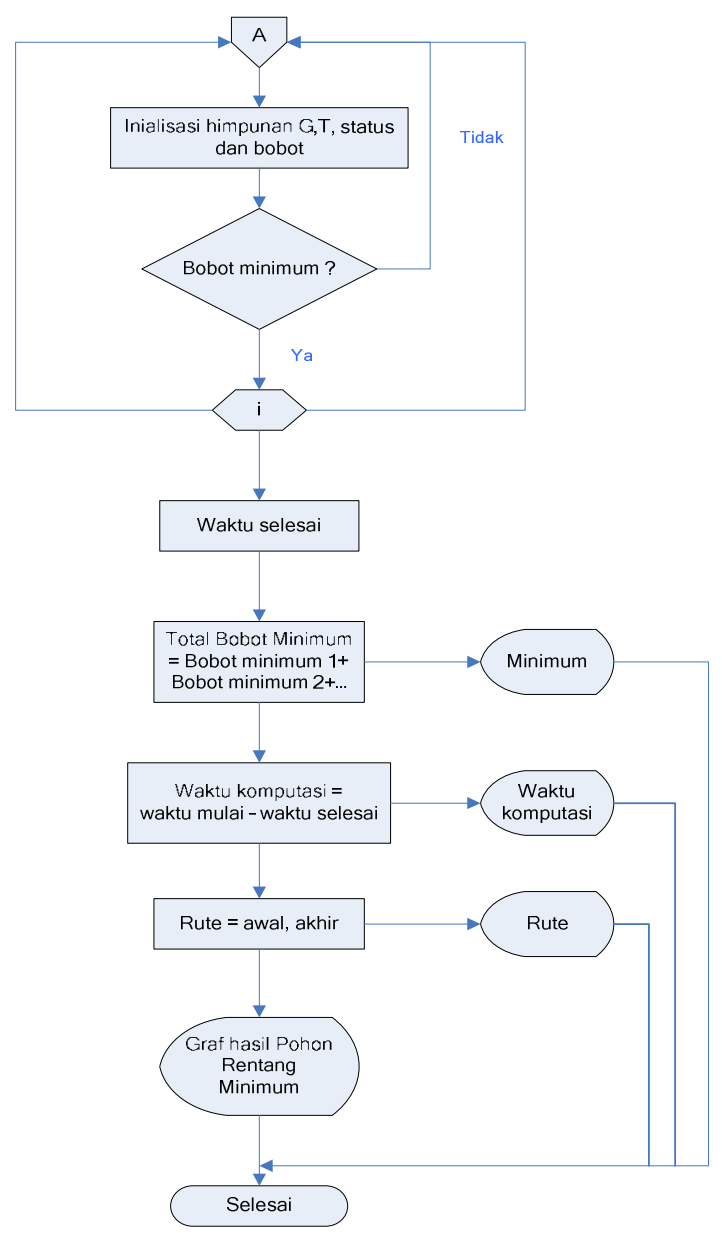

Gambar 6. Flowchart tahapan penentuan pohon rentang minimum jaringan listrik distribusi primer berdasarkan kondisi geografis suatu wilayah dengan menggunakan algortima prim

\section{Kompleksitas waktu algoritma prim}

Algoritma prim menentukan suatu pohon merentang minimum di dalam graf yang terhubung dan berbobot dengan $\mathrm{n}$ titik/simpul (jumlah data masukan). Selanjutnya akan diuji kompleksitas waktu dari algoritma prim dengan tujuan untuk mengetahui efisiensi dari algoritma tersebut. Efisiensi algoritma diukur dari berapa jumlah waktu yang dibutuhkan untuk menjalankan algoritma tersebut. Algoritma yang efisien yaitu algoritma yang meminimumkan kebutuhan waktu.

Keakuratan waktu eksekusi algoritma dapat diperoleh dengan tidak menghitung kebutuhan waktu untuk menampilkan antarmuka program, operasi masukan/keluaran (baca, tulis), dan sebagainya. Jadi, benar-benar yang dihitung adalah kebutuhan waktu untuk bagian algoritma yang inti saja (Munir, 2009).

Berdasarkan proses pencarian pohon merentang minimum jaringan distribusi listrik dengan algoritma prim, maka kompleksitas dari algoritma prim dapat dibuktikan sebagai berikut:

1. Langkah 1 (inisialisasi) dari algoritma prim memerlukan waktu paling banyak $\mathrm{n}$ operasi. Sehingga kompleksitas dari langkah ini adalah $\mathrm{O}(\mathrm{n})$.

2. Langkah 2, adalah langkah iterasi, memerlukan paling banyak n-1 kali pengujian (sebab satu titik/simpul sembarang telah dipilih pada langkah 2), sehingga kompleksitas langkah ini adalah $\mathrm{O}(\mathrm{n})$.

3. Langkah 3 dijalankan tepat $n$ kali.

Setiap kali menjalankan langkah 3, menentukan garis/sisi dengan bobot terkecil dari himpunan simpul-simpul yang belum terhubung $(G)$ ke himpunan simpul-simpul yang sudah saling 
terhubung $(\mathrm{T})$, dengan paling banyak $\mathrm{n}$ kali operasi. Sehingga langkah 3 ini memiki kompleksitas $\mathrm{O}(\mathrm{n})$.

Setelah simpul pada himpunan T terbaru ditandai, perlu untuk memperbaharui daftar simpul pada himpunan $G$. Untuk tiap simpul pada himpunan $G$, diadakan perbandingan antara bobot dari sisi terkecil dari simpul pada himpunan $F$ ke simpul pada himpunan $T$, untuk menentukan sisi dengan bobot terkecil yang menghubungkan sembarang simpul pada himpunan $\mathrm{F}$ ke sembarang simpul pada himpunan T. Proses pembaharuan tersebut dalam $\mathrm{O}(\mathrm{n})$ operasi.

Karena tidak ada satupun bagian dari langkah 3 ini yang memerlukan lebih dari $O(n)$ operasi, maka kompleksitas langkah 3 adalah $O(n)$, perlu diingat bahwa $O(n)+O(n)=O(n)$.

Karena langkah 3 dilaksanakan $n$ kali, maka operasi yang dilakukan adalah: $(n)(O(n))=$ $\mathrm{O}\left(\mathrm{n}^{2}\right)$

Sehingga kompleksitas dari semua langkah iterasi (langkah 2 dan langkah 3) adalah:

$O(n)+O\left(n^{2}\right)=O\left(n^{2}+n\right)=O\left(n^{2}\right)$

Dari menghitung kompleksitas masing-masing langkah di atas, diperoleh kompleksitas algoritma prim adalah: kompleksitas langkah 1 + kompleksitas langkah semua iterasi (langkah 2 dan langkah 3) adalah:

$f(n)=O(n)+O\left(n^{2}\right)=O\left(n^{2}+n\right)=O\left(n^{2}\right)$

Sehingga dapat disimpulkan bahwa kompleksitas waktu algoritma prim bersifat kuadratik.

\section{HASIL DAN PEMBAHASAN}

\section{Pengujian Sistem}

Pengujian sistem penentuan pohon rentang minimum berdasarkan kondisi geografis suatu wilayah menggunakan algortima prim dengan studi kasus pada Kota Samarinda dilakukan untuk mengetahui kemampuan program algoritma prim dalam menghasilkan pohon rentang minimum.

Program algoritma prim yang digunakan telah dimodifikasi untuk memasukkan parameter tinggi tiang listrik distribusi, elevasi, dan jarak antar tiang listrik distribusi untuk menghasilkan graf dengan bobot minimum.

Pengujian sistem yang dilakukan dibagi menjadi tiga bagian antara lain pengujian terhadap kondisi kontur yang berbeda dengan masukan berupa variasi jumlah simpul/titik dan jumlah sisi graf. Tujuannya untuk mengetahui kemampuan sistem dalam menghasilkan MST dengan bobot minimum serta waktu komputasi yang diperlukan sistem.

Selanjutnya pengujian terhadap jaringan listrik distribusi primer yang telah eksisting di Kota Samarinda. Tujuannya untuk mengetahui panjang minimum kabel yang riil digunakan oleh sistem jaringan listrik distribusi primer Kota Samarinda. Dalam pengujian bagian kedua ini menggunakan data tambahan berupa pengukuran manual dari panjang kabel minimum yang telah dihasilkan menggunakan peralatan GPS dengan tingkat kesalahan sebesar \pm 5 meter dari pengukuran.

Sedangkan yang terakhir adalah pengujian terhadap perencanaan jaringan listrik distribusi primer baru yang telah dipasang tiang-tiang listrik di suatu wilayah. Tujuannya untuk menentukan pohon rentang minimum suatu jaringan listrik distribusi listrik yang optimal (memiliki panjang kabel minimum serta telah sesuai dengan kondisi daerah tersebut).

Penggunaan variasi jumlah simpul, jumlah sisi, dan variasi model graf adalah untuk mendapatkan hasil pengujian berupa kemampuan algoritma prim dalam menentukan pohon rentang minimum berdasarkan masukan elevasi, tinggi tiang listrik, serta jarak antar tiang listrik. Pengujian sistem ini juga mengunakan program yang dibuat dengan ArcView GIS 3.3 dengan bantuan script avenue.

Maksud dan tujuan penggunaan program ini adalah membantu menghubungkan data elevasi, tinggi tiang listrik distribusi, serta jarak antar tiang listrik distribusi dengan metode algoritma prim untuk mendapatkan pohon rentang minimum suatu graf berbobot dan diimplementasikan dalam jaringan listrik distribusi primer Kota Samarinda.

\section{Pembahasan}

Dari proses pengujian yang telah dilakukan, maka akan diperoleh tiga bagian hasil pengujian. Bagian pertama merupakan hasil pengujian dari pengujian 1 sampai dengan 5 , dan 
bagian kedua merupakan hasil pengujian 6 sampai dengan 8 . Untuk bagian ketiga merupakan hasil pengujian 9 dan pengujian 10 .

Hasil pengujian bagian pertama menitikberatkan pada kemampuan sistem dalam menghasilkan MST dengan bobot minimum untuk kondisi kontur yang berbeda-beda. Selain itu juga untuk mengetahui waktu komputasi yang dibutuhkan oleh sistem untuk menentukan pohon rentang minimum.

Hasil pengujian 1 sampai dengan 5 dapat dibagi dua bagian yaitu bobot minimum yang dihasilkan serta waktu komputasi dari masing-masing pengujian. Secara lengkap dapat dilihat pada Tabel 1 dan Tabel 2 berikut:

Tabel 1. Waktu komputasi pengujian 1 sampai dengan 5

\begin{tabular}{|c|c|c|c|c|c|}
\hline \multirow{2}{*}{$\begin{array}{c}\text { Penguj } \\
\text { ian }\end{array}$} & $\begin{array}{c}\text { Jum } \\
\text { lah } \\
\text { sim } \\
\text { pul }\end{array}$ & $\begin{array}{c}\text { Juml } \\
\text { ah } \\
\text { sisi }\end{array}$ & $\begin{array}{c}\text { Kondis } \\
\text { i } \\
\text { kontur } \\
\text { datar }\end{array}$ & $\begin{array}{c}\text { Kondisi } \\
\text { kontur } \\
\text { berbeda }\end{array}$ & $\begin{array}{c}\text { Selisih } \\
(\Delta)\end{array}$ \\
\hline (a) & (b) & (c) & $($ d $)$ & $(e)$ & $(f)$ \\
\hline $\begin{array}{c}\text { Penguj } \\
\text { ian 1 }\end{array}$ & 20 & 49 & $10 \mathrm{sec}$ & $23 \mathrm{sec}$ & $13 \mathrm{sec}$ \\
\hline $\begin{array}{c}\text { Penguj } \\
\text { ian 2 }\end{array}$ & 30 & 80 & $54 \mathrm{sec}$ & $116 \mathrm{sec}$ & $62 \mathrm{sec}$ \\
\hline $\begin{array}{c}\text { Penguj } \\
\text { ian 3 }\end{array}$ & 40 & 104 & $\begin{array}{c}153 \\
\mathrm{sec}\end{array}$ & $372 \mathrm{sec}$ & $\begin{array}{c}219 \\
\mathrm{sec}\end{array}$ \\
\hline $\begin{array}{c}\text { Penguj } \\
\text { ian 4 }\end{array}$ & 50 & 130 & $\begin{array}{c}311 \\
\mathrm{sec}\end{array}$ & $880 \mathrm{sec}$ & $\begin{array}{c}569 \\
\mathrm{sec}\end{array}$ \\
\hline $\begin{array}{c}\text { Penguj } \\
\text { ian 5 }\end{array}$ & 60 & 163 & $\begin{array}{c}572 \\
\mathrm{sec}\end{array}$ & $\begin{array}{c}1941 \\
\mathrm{sec}\end{array}$ & $\begin{array}{c}1369 \\
\mathrm{sec}\end{array}$ \\
\hline
\end{tabular}

Tabel 2. Bobot minimum pengujian 1 sampai dengan 5

\begin{tabular}{|c|c|c|c|c|c|}
\hline \multirow[b]{2}{*}{ Pengujian } & \multirow[b]{2}{*}{$\begin{array}{l}\text { Jumlah } \\
\text { simpul }\end{array}$} & \multirow[b]{2}{*}{$\begin{array}{l}\text { Jumlah } \\
\text { sisi }\end{array}$} & \multicolumn{2}{|c|}{ Bobot Minimum } & \multirow[b]{2}{*}{$\begin{array}{c}\text { Selisih } \\
(\Delta)\end{array}$} \\
\hline & & & $\begin{array}{c}\text { Kondisi } \\
\text { kontur } \\
\text { datar }\end{array}$ & $\begin{array}{c}\text { Kondisi } \\
\text { kontur } \\
\text { berbeda }\end{array}$ & \\
\hline (a) & (b) & (c) & (d) & (e) & (f) \\
\hline Pengujian & 20 & 49 & $\begin{array}{l}3208 \\
52 \mathrm{~m}\end{array}$ & $\begin{array}{l}3218, \\
63 \mathrm{~m}\end{array}$ & $\begin{array}{c}10,11 \\
\mathrm{~m}\end{array}$ \\
\hline $\begin{array}{c}\text { Pengujian } \\
2\end{array}$ & 30 & 80 & $\begin{array}{l}4269 \\
34 \mathrm{~m}\end{array}$ & $\begin{array}{l}4289, \\
13 \mathrm{~m}\end{array}$ & $\begin{array}{c}19,79 \\
\mathrm{~m}\end{array}$ \\
\hline $\begin{array}{c}\text { Pengujian } \\
3\end{array}$ & 40 & 104 & $\begin{array}{l}5536, \\
54 \mathrm{~m}\end{array}$ & $\begin{array}{l}5568, \\
58 \mathrm{~m}\end{array}$ & $\begin{array}{c}32,04 \\
\mathrm{~m}\end{array}$ \\
\hline $\begin{array}{c}\text { Pengujian } \\
4\end{array}$ & 50 & 130 & $\begin{array}{l}6647 \\
64 \mathrm{~m}\end{array}$ & $\begin{array}{l}6690, \\
85 \mathrm{~m}\end{array}$ & $\begin{array}{c}43,21 \\
\mathrm{~m}\end{array}$ \\
\hline $\begin{array}{l}\text { Pengujian } \\
5\end{array}$ & 60 & 163 & $\begin{array}{l}8421 \\
31 \mathrm{~m}\end{array}$ & $\begin{array}{l}8476, \\
34 \mathrm{~m}\end{array}$ & $\begin{array}{c}55,03 \\
\mathrm{~m}\end{array}$ \\
\hline
\end{tabular}

Berdasarkan Tabel 1 terlihat bahwa waktu komputasi yang diperlukan algoritma prim dalam menghasilkan pohon rentang minimum (MST) mengalami kenaikan seiring pertambahan jumlah simpul dan sisi suatu graf. Selain itu waktu komputasi yang dibutuhkan algoritma prim dalam menghasilkan MST tanpa memperhatikan kondisi kontur (permukaan bumi datar) lebih cepat dibandingkan dengan memperhatikan kondisi kontur. Kondisi tersebut dapat terlihat dari selisih waktu komputasi yang semakin besar dari pengujian 1 sampai dengan 5 .

Penentuan MST berdasarkan kondisi goegrafis suatu wilayah dengan algoritma prim akan membutuhkan waktu komputasi yang lama dan apabila jika jumlah simpul dan sisi graf ditambah, maka waktu komputasi akan semakin lama. Hal ini disebabkan karena adanya 
tambahan script program pada algoritma prim berupa masukkan parameter elevasi dan tinggi tiang dari suatu graf, sehingga penentuan MST dengan algoritma prim akan mengalami penambahan proses perhitungan elevasi dan tinggi tiang untuk menghasikan bobot minimum masing-masing graf.

Hasil pengujian kompleksitas waktu algoritma prim pada Tabel 1 dengan menggunakan program ArcView GIS 3.3 berdasarkan jumlah titik/simpul (n) dapat digambarkan ke dalam grafik seperti terlihat pada Gambar 7 dan Gambar 8.

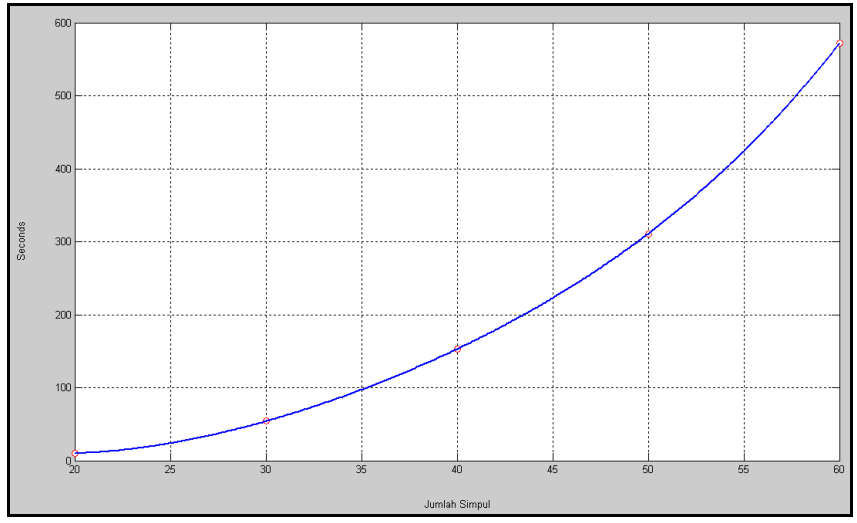

Gambar 7. Grafik kompleksitas waktu algoritma prim tanpa memperhatikan kondisi kontur

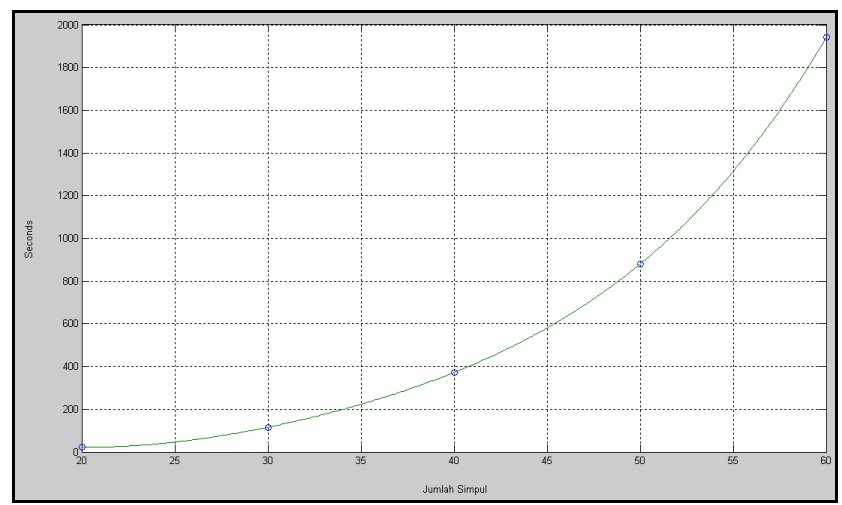

Gambar 8. Grafik kompleksitas waktu algoritma prim dengan memperhatikan kondisi kontur

Pada gambar 7 terlihat bahwa untuk jumlah simpul/titik (n) yang kecil akan membutuhkan waktu komputasi yang masih cepat. Ketika semakin banyak jumlah titik/simpul (n) yang akan diuji, maka waktu komputasinya juga akan mengalamin kenaikan yang besar (waktu semakin lama). Kondisi tersebut juga dialami oleh Gambar 8, dimana waktu komputasi akan melonjak tajam untuk jumlah simpul/titik (n) yang banyak.

Berdasarkan Gambar 7 dan Gambar 8 tampak bahwa grafik hasil pengujian kompleksitas waktu algoritma prim dalam mencari pohon merentang minimum (MST) dengan variasi jumlah titik/simpul bersifat kuadratik.

Pada Tabel 2 terlihat terjadi perbedaan antara bobot minimum yang dihasilkan oleh algoritma prim yang tidak memperhatikan kondisi kontur dengan yang memperhatikan kondisi kontur. Selain itu, selisih bobot minimum yang dihasilkan dari kedua kondisi tersebut mengalami kenaikan secara signifikan setelah jumlah titik/simpul dan sisi ditambah dalam suatu graf.

Hal ini mengindikasikan bahwa kenaikan jumlah titik/simpul serta jumlah sisi suatu graf disertai pengaruh parameter kontur suatu wilayah mengakibatkan perbedaan bobot minimum yang dihasilkan pohon MST akan semakin besar pula. Kondisi tersebut dapat dilihat pada Gambar 9. 


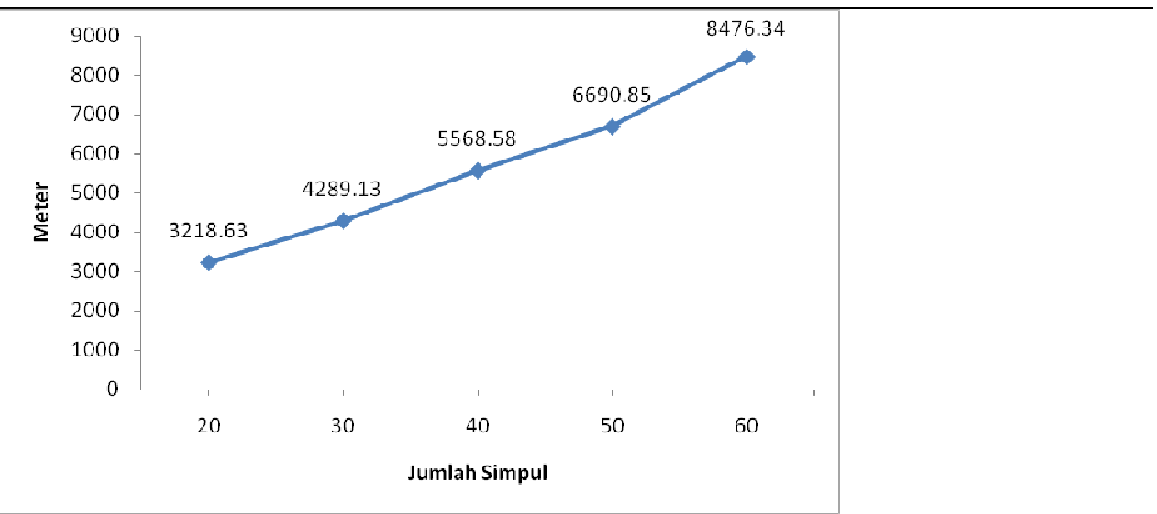

Gambar 9. Grafik bobot minimum MST berdasarkan kondisi geografis

Dari gambar 9, kenaikan jumlah titik/simpul dalam hal ini tiang listrik akan menambah bobot minimum MST berupa panjang minimum kabel yang diperlukan dalam penyambungan jaringan distribusi listrik. Kondisi ini jelas sangat membantu pihak PT. PLN (Persero) sebagai operator ketenagalistrikan di Indonesia untuk mengefisienkan dan mengoptimalkan penggunaan kabel listrik berdasarkan kondisi geografis suatu daerah/wilayah, disamping untuk mempertahankan kualitas pelayanan dan keandalan jaringan distribusi listrik.

Selanjutnya hasil pengujian bagian kedua menitikberatkan pada kemampuan algoritma prim dalam menghasilkan pohon rentang minimum (MST) yang diimplementasikan kedalam jaringan listrik distribusi primer Kota Samarinda yang telah eksisting. Dari pengimplementasiannya, diharapkan diperoleh MST jaringan listrik distribusi primer Kota Samarinda yang optimal yaitu penggunaan panjang kabel listrik yang minimum berdasarkan kondisi geografis Kota Samarinda.

Hasil pengujian bagian kedua merupakan hasil dari pengujian 6 sampai pengujian 8 . Pengujian dilakukan di tiga tempat berbeda, yaitu kawasan kampus universitas mulawarman, kawasan perkantoran DPRD Kaltim, dan kawasan pengembangan Kota Samarinda. Adapun rincian hasil pengujian 6 sampai pengujian 8 dapat dilihat pada Tabel 3 .

Tabel 3. Hasil pengujian 6 sampai dengan 8

\begin{tabular}{|c|c|c|c|c|c|}
\hline \multirow{2}{*}{ Pengujian } & \multicolumn{3}{|c|}{ Bobot Minimum } & \multicolumn{2}{c|}{ Kesalahan } \\
\cline { 2 - 6 } & $\begin{array}{c}\text { Tanpa } \\
\text { kondisi } \\
\text { geografis }\end{array}$ & $\begin{array}{c}\text { Berdasarkan } \\
\text { kondisi } \\
\text { geografis }\end{array}$ & $\begin{array}{c}\text { Referensi } \\
\text { (pengukuran } \\
\text { manual) }\end{array}$ & $\begin{array}{c}\text { Tanpa } \\
\text { kondisi } \\
\text { geografis }\end{array}$ & $\begin{array}{c}\text { Berdasarkan } \\
\text { kondisi } \\
\text { geografis }\end{array}$ \\
\hline (a) & $(b)$ & $(c)$ & $(d)$ & $(e)$ & $(f)$ \\
\hline $\begin{array}{c}\text { Pengujian } \\
6\end{array}$ & $\begin{array}{c}3100,76 \\
\mathrm{~m}\end{array}$ & $3100,76 \mathrm{~m}$ & $3103,43 \mathrm{~m}$ & $0,086 \%$ & $0,086 \%$ \\
\hline $\begin{array}{c}\text { Pengujian } \\
7\end{array}$ & $\begin{array}{c}1103,99 \\
\mathrm{~m}\end{array}$ & $1107,81 \mathrm{~m}$ & $1109,23 \mathrm{~m}$ & $0,472 \%$ & $0,128 \%$ \\
\hline $\begin{array}{c}\text { Pengujian } \\
8\end{array}$ & $\begin{array}{c}2016,77 \\
\mathrm{~m}\end{array}$ & $2087 \mathrm{~m}$ & $2091,89 \mathrm{~m}$ & $3,591 \%$ & $0,234 \%$ \\
\hline
\end{tabular}

Berdasarkan Tabel 3 terlihat bahwa kesalahan terkecil dari referensi terjadi pada bobot minimum yang didasarkan pada kondisi geografis suatu wilayah dalam hal ini data kontur (tinggi permukaan bumi). Rata-rata kesalahan untuk bobot minimum yang dihasilkan algoritma prim berdasarkan kondisi kontur sebesar 0,149 \%. Hal ini mengindikaskan bahwa bobot minimum yang dihasilkan algoritma prim untuk menentukan MST jaringan listrik distribusi primer berdasarkan kondisi kontur sudah hampir mendekati panjang kabel sebenarnya, meskipun belum $100 \%$ akurat

Sedangkan untuk bobot minimum yang dihasilkan algoritma prim yang tidak memperhatikan kondisi kontur memiliki tingkat kesalahan rata-rata sebesar $1,383 \%$ dari referensi, dengan tingkat kesalahan terbesar terjadi pada pengujian 8 yaitu sebesar $3,591 \%$. Kondisi itu terjadi 
ketika sistem tidak memperhatikan kondisi kontur yang memiliki tingkat ketinggian berbeda, contohnya pada daerah perbukitan dan pegunungan.

Dengan demikian, maka bobot minimum yang dihasilkan dari MST jaringan listrik distribusi primer tanpa memperhatikan kondisi geografis akan memiliki tingkat kesalahan yang tinggi. Hal ini mengindikasikan bahwa parameter elevasi (tinggi permukaan bumi) sangat mempengaruhi bobot minimum suatu graf dalam menghasilkan MST dengan menggunakan algoritma prim.

Pengujian selanjutnya adalah pengujian kesembilan dan kesepuluh, dimana dalam pengujian ini dilakukan perencanaan jaringan baru di daerah yang belum dialiri listrik berdasarkan kondisi geografis Kota Samarinda. Untuk pengujian kesembilan dilakukan pengembangan jaringan listrik distribusi primer di penyulang T5 untuk memberikan aliran listrik di daerah perumahan bengkuring kecamatan palaran.

Kondisi geografis daerah kawasan perumahan bengkuring memiliki ketinggian 12,5 meter diatas permukaan laut. Dari model graf jaringan listrik yang telah dirancang berdasarkan peta topografi dan kontur daerah tersebut dihasilkan rute jaringan listrik distribusi primer dengan bobot minimum sebesar 727,16 meter, yaitu pemakaian kabel listrik yang efisien dalam menghubungkan seluruh tiang listrik yang akan dipasang.

Pada pengujian kesepuluh, dilakukan perencanaan pengembangan jaringan listrik distribusi primer di kawasan perumahan mutiara indah kecamatan samarinda ilir dengan penyulang T5 sebagai sumber listriknya. Kondisi geografis daerah tersebut berada di ketinggian antara 12,5 sampai 25 meter diatas permukaan laut. Dari model graf jaringan listrik yang telah dirancang berdasarkan peta topografi dan kontur daerah tersebut dihasilkan rute jaringan listrik distribusi primer dengan bobot minimum sebesar 439,12 meter, yaitu pemakaian kabel listrik yang efisien dalam menghubungkan seluruh tiang listrik yang akan dipasang.

Berdasarkan pengujian kesembilan dan kesepuluh yang diperoleh dapat dijadikan acuan bagi tingkat manajer untuk mengambil keputusan dalam pengembangan jaringan listrik distribusi primer di daerah yang belum mendapat aliran listrik. Acuan yang dapat dilihat adalah penggunaan panjang kabel yang efisien berdasarkan kondisi goegrafis suatu wilayah serta tingkat kemampuan penghantar/kabel dalam melayani beban listrik yang akan dipasang di daerah tersebut.

\section{KESIMPULAN DAN SARAN}

\section{Kesimpulan}

Dari hasil pembahasan tentang penentuan pohon rentang minimum berdasarkan kondisi geografis suatu wilayah menggunakan algortima prim dengan studi kasus pada Kota Samarinda dapat diperoleh kesimpulan, diantaranya:

- Pohon rentang minimum dari suatu algoritma prim yang didasarkan pada kondisi kontur akan menghasilkan bobot minimum berupa panjang kabel listrik minimum yang mendekati kenyataan, dengan tingkat kesalahan rata-rata $0,149 \%$ dari referensi pengukuran secara manual.

- Bobot minimum yang dihasilkan algoritma prim tanpa memperhatikan kondisi kontur memiliki tingkat kesalahan rata-rata sebesar $1,383 \%$ dari referensi, dengan kesalahan terbesar terjadi di daerah pegunungan/perbukitan yaitu 3,591\%.

\section{Saran}

Adapun saran yang yang mungkin bermanfaat bagi kelanjutan penelitian ini, adalah pemanfaatan GIS dalam penentuan pohon rentang minimum hendaknya perlu memperhatikan optimasi program. Hal ini dimaksudkan agar proses pencarian graf berbobot dapat dilakukan dengan relatif cepat dengan kompleksitas waktu algoritma mendekati $\mathrm{O}(\mathrm{n})$. 


\section{DAFTAR PUSTAKA}

Gloor, P. A., Johnson, D. B., Makedon, F., Metaxas, P., (1993), A Visualization System for Correctness Proofs of Graph Algorithms http://www.wellesley.edu/CS/pmetaxas/visual_proofs.pdf, Computer Science Education, [19 Maret 2010].

Greenberg, H. J., (1998), Greedy Algorithm for Minimum Spanning Tree,http://glossary.computing.society.informs.org/notes/spanningtree.pdf, University of Colorado, Denver, [19 Maret 2010].

Hage, (2008), Dunia Listrik: Sistem Distribusi Tenaga Listrik, http://dunialistrik.blogspot.com/2008/12/sistem-distribusi-tenaga-listrik.html, [3 Maret 2009].

Indriati, D., (2000), Minimum Spanning Tree Pada Graf Monge, Tesis Program Studi Matematika, Universitas Gadjah Mada, Yogyakarta.

Kadir, A., (2006), Distribusi dan Utilisasi Tenaga Listrik, Universitas Indonesia Press, Jakarta.

Kristanto, A., (2008), Perancangan Sistem Informasi dan Aplikasinya, Gava Media, Yogyakarta.

Marsudi, D., (2006), Operasi Sistem Tenaga Listrik, Graha IImu, Yogyakarta.

Mehta, D. P., Sahni, S., (2005), Handbook of Data Structures and Applications, Chapman \& Hall/CRC Computer and Information Science Series, United States of America.

Munir, R., (2009), Matematika Diskrit, Edisi 3, Informatika, Bandung.

Oetomo, B. S., (2002), Perencanaan dan Pembangunan Sistem Informasi, Andi, Yogyakarta.

Pop, P. C., Zelina, I., (2004), Heuristic Algorithms for the Generalized Minimum Spanning Tree Problem, http://emis.library.cornell.edu/ journals/AUA/acta8/Pop_Zelina.pdf, Proceedings of the International Conference on Theory and Applications of Mathematics and Informatics (ICTAMI), Thessaloniki, Greece, [19 Maret 2010].

Prahasta, E., (2004), Sistem Informasi Geografis: ArcView Lanjut Pemrograman Bahasa Script Avenue, Informatika, Bandung.

Prahasta, E., (2009), Sistem Informasi Geografis: Tutorial ArcView, Informatika, Bandung.

Purbasari, I. Y., (2007), Desain Dan Analisis Algoritma, Edisi 1, Graha Ilmu, Yogyakarta.

Purwanto, E. B., (2008), Perancangan Dan Analisis Algoritma, Edisi 1, Graha llmu, Yogyakarta.

Zakaria, T. M., Prijono, A., (2006), Konsep Dan Implementasi Struktur Data, Informatika, Bandung 